\section{Forløpstider i Mammografi- programmet før og etter innføring av pakkeforløp for brystkreft}

ORIGINALARTIKKEL

\section{KAITLYN M. TSURUDA}

Mammografiseksjonen

Kreftregisteret

Hun utviklet ideen til studien sammen med Hofvind og har ledet litteratursøk, bidratt i studiedesign, vasket og analysert data, tolket resultater og vært ansvarlig for utarbeidelse og ferdigstillelse av innsendt manuskript.

Kaitlyn M. Tsuruda er M.Sc., epidemiolog og ph.d.-kandidat.

Forfatteren har fylt ut ICMJE-skjemaet og oppgir ingen interessekonflikter.

\section{SAMEER BHARGAVA}

Mammografiseksjonen

Kreftregisteret

Han har bidratt i litteratursøk, utvikling av studiedesign, tolking av data og utarbeidelse og

ferdigstillelse av innsendt manuskript.

Sameer Bhargava er lege i spesialisering og ph.d.-kandidat.

Forfatteren har fylt ut ICMJE-skjemaet og oppgir ingen interessekonflikter.

\section{LARS A. AKSLEN}

Centre for Cancer Biomarkers

Klinisk institutt 1

Universitetet i Bergen

og

Avdeling for patologi

Haukeland universitetssjukehus

Han har bidratt i studiedesign, tolking av resultater og utarbeidelse og ferdigstillelse av innsendt manuskript.

Lars A. Akslen er dr.med., spesialist i patologi, professor og overlege. Han er leder for Centre for Cancer Biomarkers, Universitetet i Bergen, og for Mammografiprogrammets faggruppe i patologi. Forfatteren har fylt ut ICMJE-skjemaet og oppgir ingen interessekonflikter.

\section{HILDE BJØRNDAL}

Brystdiagnostisk senter Vestre Viken, Drammen

Hun har bidratt i tolking av resultater og utarbeidelse og ferdigstillelse av innsendt manuskript. Hilde Bjørndal er spesialist i brystradiologi og overlege. Hun er leder for Mammografiprogrammets faggruppe i radiologi.

Forfatteren har fylt ut ICMJE-skjemaet og oppgir ingen interessekonflikter. 
E-post: solveig.hofvind@kreftregisteret.no

Mammografiseksjonen

Kreftregisteret

og

Institutt for naturvitenskapelige helsefag

Oslomet-storbyuniversitetet

Hun hadde ideen til studien og har bidratt i litteraturs $ø$, studiedesign, tolking av resultater og

utarbeidelse og ferdigstillelse av innsendt manuskript.

Solveig Hofvind er leder for Mammografiprogrammet og professor.

Forfatteren har fylt ut ICMJE-skjemaet og oppgir ingen interessekonflikter.

\section{BAKGRUNN}

Målsettingen med å innføre "pakkeforløp for brystkreft» var blant annet å sikre et helhetlig forløp uten unødvendige forsinkelser. Radiologer og patologer som arbeider med brystdiagnostikk, er involverte både i pakkeforløpet og i Mammografiprogrammet. Hvorvidt innføringen kan ha påvirket forløpstider i Mammografiprogrammet, er ikke analysert tidligere. Denne studien presenterer forløpstider i Mammografiprogrammet før og etter innføring av pakkeforløpet.

\section{MATERIALE OG METODE}

Vi analyserte forløpstider for 1485240 screeningundersøkelser utført i Mammografiprogrammet i perioden 1.7.2011-30.6.2018 etter brystdiagnostisk senter. Forløpstider var definert som antall kalenderdager fra a) screeningundersøkelse til screeningmammogrammene var tydet og negativt svarbrev var sendt (ventetid), b) screeningundersøkelse til etterundersøkelse var utført (etterundersøkelsestid) og c) etterundersøkelse til diagnose (diagnosetid). Data ble hentet fra Kreftregisterets databaser. Bruk av disse er hjemlet i Kreftregisterforskriften. Vi beregnet mediane forløpstider i tillegg til go prosentiler.-prosentiler.

\section{RESULTATER}

Median ventetid var 13 dager før og 12 dager etter innføring av pakkeforløpet. Median etterunders $\emptyset$ kelsestid $\emptyset$ kte fra 23 til 27 dager, mens median diagnosetid var 3 dager både før og etter innføring av pakkeforløpet.

\section{FORTOLKNING}

Vente- og diagnosetid var uendret, eller endret kun i liten grad etter innføring av pakkeforløpet, mens etterundersøkelsestid var noe øket. Innføring av pakkeforløpet kan ha ført til ulike justeringer i prioriteringer, arbeidsflyt og ressurstilgang ved de brystdiagnostiske sentrene.

Tilgang til helsetjenester kan indikere hvordan helsevesenet fungerer. Unødvendig lang ventetid ved mistanke om alvorlig sykdom kan gi uro, engstelse og forsinket diagnose. Kvinner som diagnostiseres med brystkreft i et tidlig stadium har bedre overlevelse enn de som får diagnostisert sykdommen sent (1). Flere europeiske land har etablert retningslinjer for forløpstider ved utredning av kreft (2-5). Forløpstidene er i all hovedsak knyttet til utredning av kvinner med symptomer på brystkreft.

Tidligere var forløpstider for utredning ved mistanke om brystkreft spesifisert i Nasjonalt handlingsprogram for brystkreft i Norge (6). I 2015 ble disse erstattet da Helsedirektoratet innførte pakkeforløp for 28 kreftformer (7). Målet med pakkeforløp er at «... pasienter skal oppleve et godt organisert, helhetlig og forutsigbart forløp uten unødvendig ikkemedisinsk begrunnede forsinkelser i utredning, diagnostikk, behandling og rehabilitering» (8). De første pakkeforløpene ble innført 1. januar 2015 for de fire hyppigste kreftformene i 
Norge: brystkreft, lungekreft, tykk- og endetarmskreft og prostatakreft. Målet er at 70 \% av brystkreftpasientene skal utredes i et pakkeforl $\emptyset \mathrm{p}$ (8). Foreløpige resultater fra 2018 viser at $88 \%$ av alle kvinner diagnostisert med brystkreft ble inkludert i pakkeforløpet. Andelen var høyest i Helse Vest (> 90 \%) og lavest i Helse Midt-Norge (om lag 85\%) (9).

I henhold til pakkeforløpet for brystkreft, heretter omtalt som pakkeforløpet, skal kvinner henvises til dette ved begrunnet mistanke om brystkreft (10). Dette gjelder også kvinner som har deltatt i Mammografiprogrammet. Kvinner som har deltatt i screeningprogrammet, inkluderes derfor i pakkeforløpet først etter at suspekte mammografifunn er diskutert på konsensusmøte og vurdert til å med høy sannsynlighet være brystkreft, eller etter at etterundersøkelsen har gitt høy mistanke om brystkreft (11). Mellom 2 og 4 \% av kvinnene som deltar i Mammografiprogrammet, innkalles til etterundersøkelse på det lokale brystdiagnostiske senter, heretter kalt brystsenter, på grunn av funn på screeningmammogrammene (12).

I Mammografiprogrammet finnes det også andre forløpstider som representerer viktige kvalitetsindikatorer. Tid fra screeningundersøkelse til negativt svarbrev er sendt og til etterundersøkelse er utført, er viktige kvalitetsparametere, men omfattes ikke av pakkeforløpet. Tid fra etterunders $\emptyset$ kelse til patologidiagnose, derimot, er inkludert både i pakkeforløpet og som en kvalitetsindikator i programmet. Alle disse tre forløpstidene er knyttet til perioden før en eventuell kreftdiagnose foreligger. Retningslinjene i

pakkeforløpet angir syv kalenderdager fra henvisningen er mottatt på utredende avdeling eller brystsenter til første fremmøte, og syv kalenderdager fra første fremmøte til avsluttet utredning (beslutning tas) som akseptable (10).

Kvalitetsmanualen for Mammografiprogrammet anbefaler at etterundersøkelsestiden ikke skal være lengre enn 21 kalenderdager og og at diagnosetiden ikke skal være lengre enn 14 kalenderdager. Gjeldende versjon av Kvalitetsmanualen for Mammografiprogrammet ble utgitt i 2003, tolv år før innføring av pakkeforløpet (11).

Innføring av pakkeforløpet har ført til endringer i prioriteringer og prosedyrer ved brystsentrene for å kunne oppfylle kravene som stilles. Hvorvidt dette har påvirket forløpstidene i Mammografiprogrammet er ikke vurdert tidligere.

Målsetningen med denne deskriptive studien er å beskrive forløpstider i Mammografiprogrammet før og etter innføring av pakkeforløpet. Resultatene vil bli stratifisert etter brystsenter.

\section{Materiale og metode}

Mammografiprogrammet inviterer kvinner mellom 50 og 69 år til mammografiscreening hvert annet år (12). Alle screeningmammogrammene tydes uavhengig av to radiologer. Ved suspekte funn på mammogrammene, markert av den ene eller begge radiologene, diskuteres disse på et konsensusmøte hvor det blir bestemt om kvinnene skal kalles inn til etterundersøkelse (figur 1 ). 


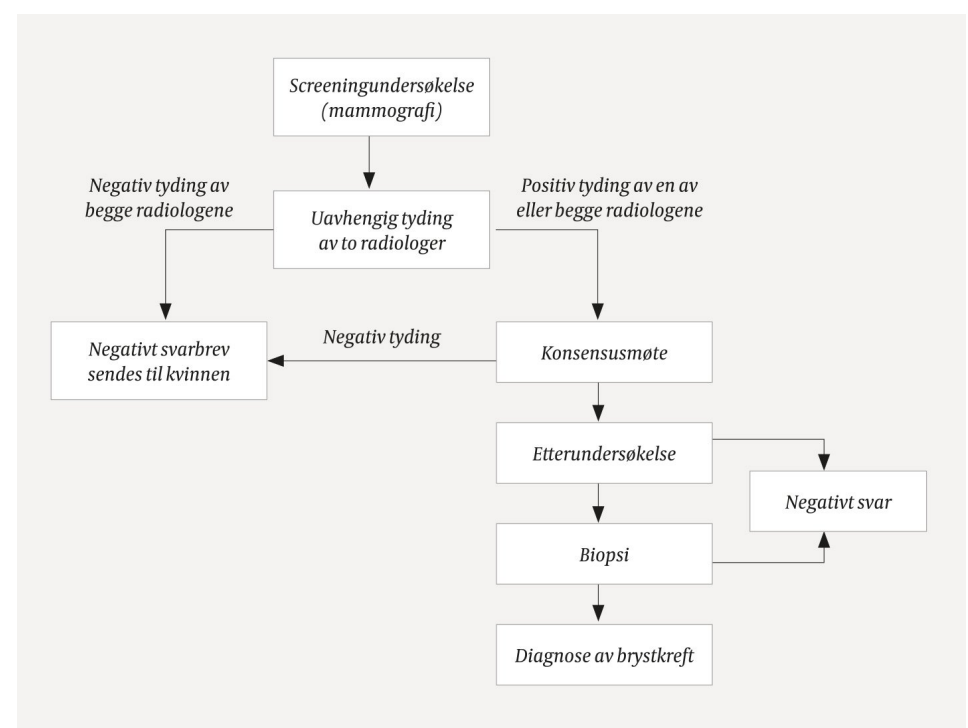

Figur 1 Pasientflyt i Mammografiprogrammet.

Screeningundersøkelser foregår på 29 screeningenheter, mens etterundersøkelser, diagnostisering og videre oppfølging skjer ved 16 brystsentre som dekker områder som i hovedsak følger fylkesgrensene. Tyding av screeningmammogrammer, etterunders $ø$ kelser, utredning og eventuell oppfølging skjer ved brystsentrene (12). Kreftregisteret har ansvar for utsendelse av negative svarbrev. Brystsentrene sender brev eller ringer kvinnen og gir beskjed om at funn på screeningmammogrammene gjør det nødvendig med etterundersøkelse. De har også ansvar for å gi svar på etterundersøkelsen.

Vi analyserte tre forløpstider i Mammografiprogrammet: ventetid, etterundersøkelsestid og diagnosetid (tabell 1). Ventetid ble definert som antall kalenderdager mellom screeningunders $\varnothing$ kelse og utsendelse av negativt svarbrev, mens etterunders $ø$ kelsestid ble definert som antall dager mellom screeningundersøkelse og etterundersøkelse.

Diagnosetid ble definert som antall dager mellom dato for etterunders $ø$ kelse og dato for besvart patologimelding (første signerte maligne patologiresultat - duktalt carcinoma in situ eller infiltrerende brystkreft). Etterundersøkelser omfatter kvinner som ble tilbakekalt for videre utredning på grunn av suspekte mammografiske funn, tekniske utilfredsstillende bilder og kvinner som oppga symptomer ved oppmøte til screening.

\section{Tabell 1}

Definisjon av forløpstider i Mammografiprogrammet.

\begin{tabular}{|llc|}
\hline Forløpstid & Definisjon & $\begin{array}{l}\text { Inkludert i } \\
\text { pakkeforløp for } \\
\text { brystkreft? }\end{array}$ \\
\hline Ventetid & $\begin{array}{l}\text { Antall kalenderdager mellom } \\
\text { screeningundersøkelsen og utsendelse av } \\
\text { negativt svarbrev }\end{array}$ & Nei \\
\hline Etterundersøkelsestid & $\begin{array}{l}\text { Antall kalenderdager mellom } \\
\text { screeningundersøkelsen og etterundersøkelsen }\end{array}$ & Nei \\
\hline Diagnosetid & $\begin{array}{l}\text { Antall kalenderdager mellom dato for } \\
\text { etterundersøkelse og dato for besvart } \\
\text { patologimelding (første signerte maligne } \\
\text { patologiresultat - duktalt carcinoma in situ eller } \\
\text { infiltrerende brystkreft) }\end{array}$ & Ja \\
\hline
\end{tabular}

Informasjon om forløpstider for alle screeningundersøkelser utført i perioden 1.7.2011-30.6.2018 (studieperioden) ble innhentet fra Kreftregisterets databaser. Ventetid og etterundersøkelsestid ble analysert for hele studieperioden, mens diagnosetidsanalysene ble begrenset til perioden 1.1.2012-31.12.2017 på grunn av ukomplett kreftregistering i 2018. 
Bruk av opplysninger til studien er hjemlet i Kreftregisterforskriften (13).

Vi viser median, gjennomsnitt og 9o-prosentil for de ulike forløpstidene etter år, i linjediagram for å illustrere trender. 9o-prosentilen angir verdier for $90 \% \mathrm{av}$ screeningundersøkelsene og ble valgt fordi vi ønsket å illustrere resultatet for majoriteten av kvinnene som møtte til screening. Videre viser vi median forløpstid i dager med $95 \%$ konfidensintervall og 9o-prosentil før og etter innføring av pakkeforløpet. Andel forløpstider innenfor anbefalingene i Mammografiprogrammets kvalitetsmanual blir også presentert. Vi har tidligere vist ulike forløpstider ved brystsentrene og antok derfor at senter er en mulig effektmodifikator (14). Resultatene ble derfor stratifisert etter brystsenter.

STATA versjon 15.1 (Stata/MP, StataCorp Texas, USA) ble benyttet til alle beregninger og for å fremstille grafiske figurer.

\section{Resultater}

I studieperioden ble det utført 1485240 screeningundersøkelser blant 607105 kvinner (tabell 2). Kvinnene hadde i gjennomsnitt 2,5 og 2,4 undersøkelser (variasjon 1 til 3) henholdsvis før og etter innføring av pakkeforløpet. Det ble utført $706414(47,6 \%)$ undersøkelser før og $778826(52,4 \%)$ etter at pakkeforløpet ble innført. Raten av screeningoppdaget brystkreft var o,55\% i studieperioden.

\section{Tabell 2}

Antall kvinner, antall screeningundersøkelser, alder ved screening og resultater av screeningundersøkelser i Mammografiprogrammet før (1.7.2011-31.12.2014) og etter (1.1.2015-30.6.2018) innføringen av pakkeforløp for brystkreft.

\begin{tabular}{|lrr|}
\hline & Innføring av pakkeforløp for brystkreft \\
\hline & Før & Etter \\
\hline Kvinner, $\mathrm{n}$ & 280636 & 326469 \\
\hline Screeningundersøkelser, $\mathrm{n}$ & 706414 & 778826 \\
\hline Alder ved screening, gjennomsnitt (SD) år & $59(5,8)$ & $59(5,9)$ \\
\hline Negativt svarbrev sendt, $\mathrm{n}(\%)$ & $684156(96,8 \%)$ & $750794(96,4 \%)$ \\
\hline Etterundersøkelser, $\mathrm{n}(\%)$ & $22258(3,2 \%)$ & $28032(3,6 \%)$ \\
\hline Screeningoppdaget brystkreft, $\mathrm{n}(\%)$ & $3250(0,52 \%)^{1}$ & $3790(0,57 \%)^{2}$ \\
\hline
\end{tabular}

${ }^{1}$ For perioden 1.1.2012-31.12.2014

${ }^{2}$ For perioden 1.1.2015-31.12.2017

TID FRA SCREENINGUNDERS $\varnothing$ KELSE TIL UTSENDELSE AV NEGATIVT SVARBREV (VENTETID)

Median ventetid før og etter innføring av pakkeforløpet var henholdsvis 13 og 12 dager (tabell 3, figur 2). 9o-prosentilen var 30 dager både før og etter innføringen. Det var stor variasjon i median ventetid og 9o-prosentil mellom brystsentrene både før og etter innføringen (variasjon i median ventetid fra 8 til 43 dager før, og fra 7 til 35 dager etter innføringen, og variasjon i 9o-prosentilen fra 13 til 62 dager før og fra 12 til 71 dager etter). De fleste sentrene hadde en median ventetid nær medianverdien for hele landet, unntatt ett senter hvor tiden var 43 dager før og 35 etter (figur 3). Det var minimale endringer i median ventetid før og etter innføring av pakkeforløpet ved alle sentrene, bortsett fra ved ett senter hvor det var en betydelig nedgang (tabell 3 ). 


\section{Tabell 3}

Antall kalenderdager fra screeningundersøkelse til utsendelse av negativt svarbrev (ventetid) og til etterundersøkelse (etterundersøkelsestid), og fra etterundersøkelse til prøven ble besvart av patolog (diagnosetid) blant kvinner som deltok $\mathrm{i}$ Mammografiprogrammet før (1.7.2011-31.12.2014) og etter (1.1.2015-30.6.2018) innføringen av pakkeforløpet for brystkreft. Tidene er angitt som median antall kalenderdager (90prosentil).

\begin{tabular}{|c|c|c|c|c|c|c|}
\hline \multirow{2}{*}{$\begin{array}{l}\text { Brystdiagnostisk } \\
\text { senter }\end{array}$} & \multicolumn{2}{|c|}{ Ventetid } & \multicolumn{2}{|c|}{ Etterundersøkelsestid } & \multicolumn{2}{|c|}{ Diagnosetid } \\
\hline & Før & Etter & Før & Etter & Før $^{1}$ & Etter $^{2}$ \\
\hline A & $11(18)$ & $12(18)$ & $23(41)$ & $30(45)$ & $2(6)$ & $1(6)$ \\
\hline B & $13(20)$ & $11(20)$ & $29(53)$ & $25(40)$ & $5(8)$ & $5(7)$ \\
\hline C & $12(16)$ & $10(14)$ & $17(28)$ & $17(29)$ & $7(18)$ & $7(13)$ \\
\hline D & $9(19)$ & $10(21)$ & $18(39)$ & $25(42)$ & $5(25)$ & $5(21)$ \\
\hline $\mathrm{E}$ & $13(23)$ & $14(31)$ & $16(34)$ & $20(40)$ & $5(12)$ & $2(7)$ \\
\hline $\mathrm{F}$ & $21(32)$ & $18(39)$ & $38(68)$ & $41(79)$ & $4(25)$ & $3(15)$ \\
\hline G & $8(13)$ & $7(12)$ & $14(25)$ & $12(19)$ & $3(9)$ & $3(30)$ \\
\hline $\mathrm{H}$ & $19(30)$ & $21(31)$ & $26(40)$ & $28(44)$ & $5(22)$ & $5(10)$ \\
\hline 1 & $16(26)$ & $12(28)$ & $26(46)$ & $26(48)$ & $3(7)$ & $3(8)$ \\
\hline J & $14(21)$ & $10(21)$ & $21(39)$ & $16(34)$ & $2(7)$ & $2(7)$ \\
\hline $\mathrm{K}$ & $12(19)$ & $10(17)$ & $16(29)$ & $16(28)$ & $2(6)$ & $2(6)$ \\
\hline L & $12(27)$ & $10(20)$ & $21(42)$ & $21(39)$ & $4(9)$ & $1(7)$ \\
\hline M & $10(15)$ & $11(22)$ & $20(35)$ & $22(37)$ & $6(7)$ & $5(7)$ \\
\hline $\mathrm{N}$ & $14(23)$ & $15(35)$ & $24(39)$ & $33(62)$ & $4(8)$ & $4(8)$ \\
\hline 0 & $11(17)$ & $8(14)$ & $19(33)$ & $25(41)$ & $5(15)$ & $5(8)$ \\
\hline $\mathrm{P}$ & $43(62)$ & 35 (71) & $62(92)$ & 59 (112) & $2(6)$ & $2(6)$ \\
\hline Samlet & $13(30)$ & $12(30)$ & $23(55)$ & $27(57)$ & $3(11)$ & $3(9)$ \\
\hline
\end{tabular}

1.1.2012-31.12.2014

${ }^{2} 1.1 .2015-31.12 .2017$
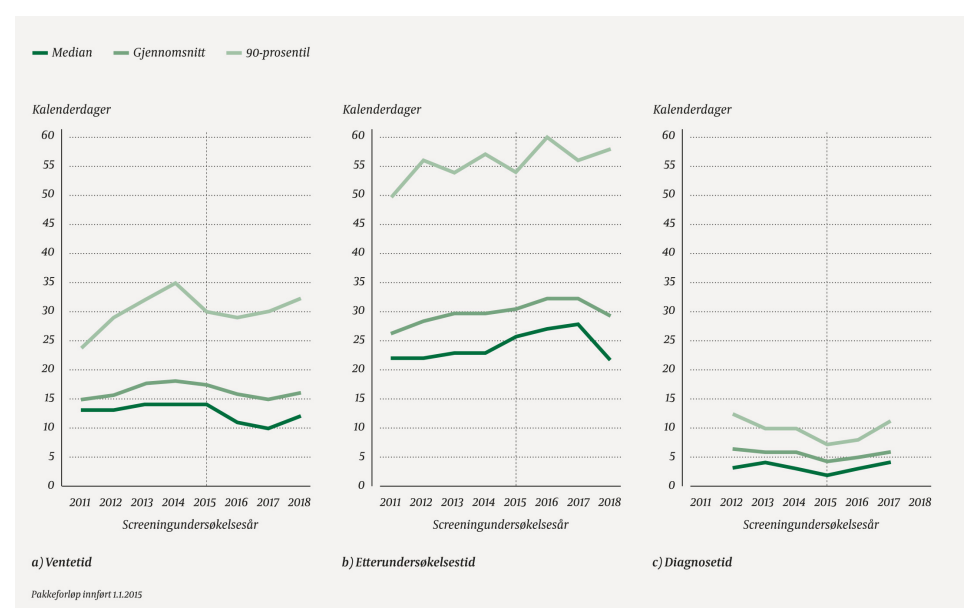

Figur 2 Forløpstider i Mammografiprogrammet før (1.7.2011-31.12.2014) og etter(1.1.2015-30.6.2018) innføring av pakkeforløp for brystkreft $i 2015$ (loddrett linje): a) ventetid = tid fra screeningunders $ø$ kelse til utsendelse av negativt svarbrev, b) etterunders $ø$ kelsestid = tid fra screeningunder $ø$ kelse til etterunders $ø$ kelse og c) diagnosetid = tid fra etterunders $ø$ kelse til diagnose av screeningoppdaget brystkreft. Forløpstider for diagnosetid er begrenset til periodene 1.1.2012-31.12.2014 og 1.1.2015-21.12.2017. 


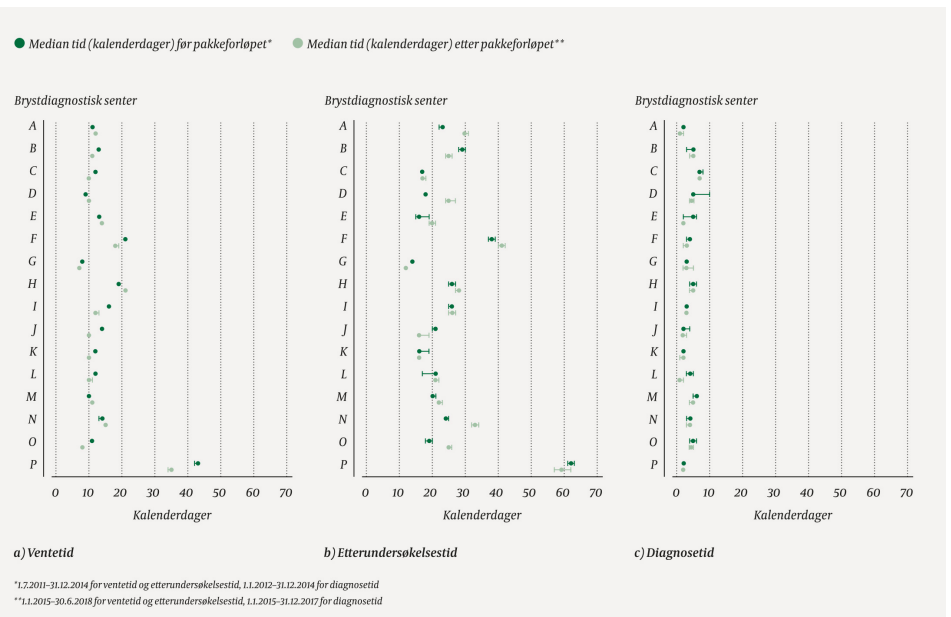

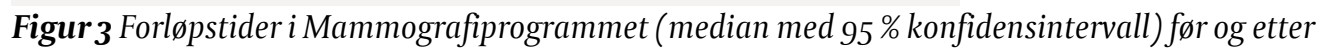
innføring av pakkeforløp for brystkreft ved de ulike brystdiagnostiske sentrene: a) ventetid = tid fra screeningundersøkelse til utsendelse av negativt svarbrev, b) etterunders $\varnothing$ kelsestid = tid fra screeningunders $\emptyset$ kelse til etterunders $\emptyset$ kelse og c) diagnosetid = tid fra etterunders $\emptyset$ kelse til diagnose av screeningoppdaget brystkreft. Forløpstider for diagnosetid er begrenset til periodene 1.1.2012-31.12.2014 og 1.1.2015-21.12.2017.

\section{TID FRA SCREENINGUNDERS $\varnothing K E L S E$ TIL ETTERUNDERS $\varnothing K E L S E$} (ETTERUNDERSØKELSESTID)

Median etterundersøkelsestid økte fra 23 før til 27 dager etter innføring av pakkeforløpet i hele landet, mens 9o-prosentilen økte fra 55 før til 57 dager etter (tabell 3). I likhet med ventetid varierte også etterundersøkelsestid mellom brystsentrene (figur 3). Median etterundersøkelsestid varierte fra 14 til 62 dager før, og fra 12 til 59 dager etter innføring av pakkeforløpet. 9o-prosentilen varierte fra 25 til 92 dager før, og fra 19 til 112 dager etter. En $ø$ kning i median etterundersøkelsestid på fem dager eller mer etter innføringen ble observert ved fire brystsentre (A, D, N, O), mens senter J hadde en tilsvarende reduksjon. Det var noe variasjon mellom go-prosentilen i etterundersøkelsestid mellom brystsenterne. Den største økningen var på 20 dager, ved senter P (tabell 3).

Etter innføringen falt andelen kvinner som fikk utført etterundersøkelse innen 21 dager fra screeningundersøkelsen fra $46 \%$ til $38 \%$ (tabell 4 ). I alt seks sentre $\emptyset$ kte andelen etterundersøkelser utført innen 21 dager.

\section{Tabell 4}

Prosentandel undersøkelser hvor forløpstider var innenfor retningslinjene i Kvalitetsmanualen, før (1.7.2011-31.12.2014) og etter (1.1.2015-30.6.2018) innføring av pakkeforløp for brystkreft.

\begin{tabular}{|c|c|c|c|c|}
\hline \multirow[t]{2}{*}{$\begin{array}{l}\text { Brystdiagnostisk } \\
\text { senter }\end{array}$} & \multicolumn{2}{|c|}{$\begin{array}{r}\leq 21 \text { dager fra } \\
\text { screeningundersøkelse til } \\
\text { etterundersøkelse }\end{array}$} & \multicolumn{2}{|c|}{$\begin{array}{r}\leq 14 \text { dager fra } \\
\text { etterundersøkelse til prøven } \\
\text { ble besvart av patolog }\end{array}$} \\
\hline & Før & Etter & Før ${ }^{1}$ & Etter $^{2}$ \\
\hline A & 43 & 24 & 97 & 97 \\
\hline$B$ & 22 & 40 & 96 & 99 \\
\hline C & 72 & 71 & 86 & 97 \\
\hline D & 57 & 35 & 78 & 88 \\
\hline$E$ & 65 & 59 & 95 & 98 \\
\hline $\mathrm{F}$ & 9 & 14 & 83 & 89 \\
\hline $\mathrm{G}$ & 86 & 95 & 94 & 76 \\
\hline $\mathrm{H}$ & 34 & 31 & 84 & 93 \\
\hline I & 41 & 43 & 98 & 97 \\
\hline
\end{tabular}




\begin{tabular}{|c|c|c|c|c|}
\hline \multirow[t]{2}{*}{$\begin{array}{l}\text { Brystdiagnostisk } \\
\text { senter }\end{array}$} & \multicolumn{4}{|c|}{$\begin{array}{rr}\leq 21 \text { dager fra } & \leq 14 \text { dager fra } \\
\text { screeningundersøkelse til } & \text { etterundersøkelse til prøven } \\
\text { etterundersøkelse } & \text { ble besvart av patolog }\end{array}$} \\
\hline & Før & Etter & Før ${ }^{1}$ & Etter $^{2}$ \\
\hline $\mathrm{J}$ & 57 & 64 & 94 & 97 \\
\hline $\mathrm{K}$ & 74 & 73 & 98 & 97 \\
\hline $\mathrm{L}$ & 56 & 51 & 95 & 99 \\
\hline$M$ & 59 & 43 & 96 & 96 \\
\hline $\mathrm{N}$ & 39 & 22 & 96 & 94 \\
\hline $\mathrm{O}$ & 67 & 36 & 88 & 96 \\
\hline $\mathrm{P}$ & 6 & 14 & 97 & 97 \\
\hline Samlet & 46 & 38 & 93 & 94 \\
\hline
\end{tabular}

1.1.2011-31.12.2014

${ }^{2} 1.1 .2015-31.12 .2017$

TID FRA ETTERUNDERS $\varnothing K E L S E$ TIL PRØVEN BLE BESVART AV PATOLOG (DIAGNOSETID)

Median diagnosetid for hele landet ble ikke endret etter innføring av pakkeforløpet (3 dager), men verdien for 9o-prosentilen ble redusert fra 11 til 9 dager etter innføringen (tabell 3).

Som med øvrige forløpstider varierte diagnosetid mellom brystsentrene før og etter innføringen, både for medianverdier (variasjon fra 2 til 7 dager før og fra 1 til 7 dager etter) og 9o-prosentilen (variasjon fra 6 til 25 dager før og fra 6 til 30 dager etter). Median diagnosetid ble redusert med én til tre dager ved fem sentre etter innføringen, mens tiden var uendret ved de elleve andre sentrene etter endringen (figur 3). Resultater for 9oprosentilen endret seg derimot mer ved enkelte sentre, spesielt ved senter G, hvor den økte med 21 dager etter innføringen.

Andelen patologiremisser som ble besvart i løpet av to uker etter etterundersøkelse, økte fra 93 \% i perioden før til $94 \%$ i perioden etter innføring av pakkeforløpet (tabell 4 ). Det var noe variasjon mellom brystsentrene, men en større andel diagnoser ble rapportert innen 14 dager etter endringen ved ni sentre. En nedgang på ett til to prosentpoeng ble observert ved tre sentre $(\mathrm{I}, \mathrm{K} \operatorname{og} \mathrm{N})$. Ved ett senter $(\mathrm{G})$ ble det observert en nedgang på 18 prosentpoeng (fra $94 \%$ til $76 \%)$.

\section{Diskusjon}

Vår studie viste at median ventetid i Mammografiprogrammet i liten grad var endret etter innføringen av pakkeforløp for brystkreft, mens median etterundersøkelsestid økte etter innføringen. Vi fant relativt store forskjeller i forløpstider mellom brystsentrene, både før og etter innføring av pakkeforløpet. Hvorvidt innføringen kan ha påvirket sentrene ulikt, er ikke undersøkt i denne studien. Vi vil allikevel anta at faktorer som kan påvirke forløpstidene, slik som prioriteringer, arbeidsflyt og ressurstilgang, kan være løst ulikt ved de 16 senterne.

Mens vente- og etterundersøkelsestid er knyttet til radiologiske ressurser, er diagnosetiden i tillegg knyttet til patologiressurser. Med begrensede ressurser må brystsentrene prioritere arbeidet som skal gjøres. Brystradiologene har begrenset tilgang på personell og tid og må prioritere screening mot klinisk arbeid. Vi synes at kvinner med symptomer på brystkreft skal prioriteres foran tyding av screeningundersøkelser, hvor om lag $97 \%$ av unders $ø$ kelser er negative (12). Et godt organisert brystsenter har imidlertid gode modeller og logistikk for optimale løsninger for begge gruppene.

Median tid fra screeningundersøkelse til etterundersøkelse økte med fire dager etter innføring av pakkeforløpet. Siden 2005 har tilbakekallingsratene vært relativt stabile samtidig som antall deltakere har økt (12). Det har derfor vært en økning i antall kvinner 
som kalles inn til etterundersøkelse. I tillegg rapporterer brystsentrene om et $\emptyset \mathrm{kt}$ antall henvisninger til mammografi fra fastleger. Vi har ingen opplysninger om hvorvidt ressursene til å håndtere dette har økt tilsvarende.

For hele landet var etterundersøkelsestid lengre enn anbefalt i Mammografiprogrammets kvalitetsmanual, spesielt etter innføringen av pakkeforløpet. Forskjellene var store mellom brystsentrene. Forløpstiden kan være påvirket av tilgjengeligheten av radiologer til å tyde screeningundersøkelsene og kapasiteten til å gjennomføre etterundersøkelser, men trolig også av prioriteringer, administrative prosedyrer og arbeidsflyt ved sentrene. Tiltak for å redusere etterundersøkelsestid bør rettes særlig mot de sentrene hvor forløpstidene er mye lengre enn anbefalt. Gjennomgang av egne og andres prosedyrer, samt hospitering, kan bidra til verdifull kunnskapsutveksling for å redusere forløpstidene.

Kvinnene får ofte svar på nåleprøven noen dager etter at den er tatt, mens det signerte patologisvaret ferdigstilles senere. Resultatene våre tyder på at innføringen av pakkeforløpet ikke har påvirket tid til ferdigstilling av patologisvarene i stor grad, men en $\emptyset$ kning i go-prosentilen ved noen sentre kan indikere at noen diagnoser er vanskeligere å ferdigstille eller at det er begrensende patologiressurser i forhold til kravene i pakkeforløpet.

Denne studien representerer registerbaserte analyser av forløpstider i

Mammografiprogrammet. Forløpstider for kvinner som blir utredet på grunn av symptomer, var ikke omfattet av vår problemstilling. En svakhet i studien er at vi ikke har informasjon om enkelte faktorer som kan føre til forsinkelser i forløpstidene. Dette kan være pasientens preferanser (for eksempel kvinner som ønsker å utsette time til etterundersøkelse), kapasitet ved brystsentrene til å utføre diagnostiske undersøkelser og tilgjengelighet av helsepersonell samt andre system-relaterte forsinkelser. Vi har heller ikke informasjon om den eksakte datoen kvinnene mottok informasjon om brystkreftdiagnose ettersom denne informasjonen ikke registreres av Kreftregisteret. Vi hadde ikke mulighet til å kontrollere for forskjeller mellom brystsentrene, noe som gjør det vanskelig å sammenligne stratifiserte resultater. Like fullt er det en målsetning ved Mammografiprogrammet å gi et likeverdig tilbud av høy kvalitet til kvinner bosatt i hele landet. Alle kvinner får tilbud om å delta i programmet, men vi mener at kvinnene som deltar også bør ha rimelig like forløpstider både før og etter at eventuell kreftdiagnose er histologisk verifisert, uavhengig av hvilket brystsenter de tilhører. En styrke ved denne studien er at den er populasjonsbasert, og at det derfor er liten sannsynlighet for å bli påvirket av seleksjonsskjevhet eller pasienter som ikke er fulgt opp. Mer enn $99 \%$ av de diagnostiserte brystkrefttilfellene fanges opp av Kreftregisteret (15).

Forløpstider er viktige kvalitetsparametere i et screeningprogram, men så vidt vi vet, finnes det ingen evidens for optimale tider. Vi anser at en kort ventetid for å få utført etterundersøkelser og for å få svar på nåleprøver bidrar til å redusere angst og uro $(16,17)$, men at tiden likevel bør være lang nok til å sikre at diagnosen blir korrekt. Dette vil også ivareta kvinnenes behov for informasjon om diagnosen slik at de har bedre mulighet til å ta informerte valg om behandling.

Vi har vist at vente- og diagnosetid i Mammografiprogrammet var uendret eller kun i liten grad endret etter innføring av pakkeforløpet, mens etterundersøkelsestid var noe økt.

\section{HOVEDFUNN}

Tid fra screeningundersøkelse til utført etterundersøkelse økte fra 23 til 27 dager etter innføring av pakkeforløp for brystkreft

De to andre undersøkte forløpstidene i Mammografiprogrammet var uendrede eller kun i liten grad endret etter innføring av pakkeforløpet

Forløpstidene varierte mellom de 16 brystsentrene 


\section{LITTERATUR:}

1. Cancer in Norway 2016 - cancer incidence, mortality, survival and prevalence in Norway. Oslo: Kreftregisteret, 2017. https://www.kreftregisteret.no/globalassets/cancer-in-norway/2016/cin-2106.pdf Lest 25.4.2019.

2. Pakkeforløb for brystkræft. København: Sundhedsstyrelsen, 2016.

https://www.sst.dk/da/udgivelser/2018/pakkeforloeb-for-brystkraeft Lest 25.4.2019.

3. NHS England. Waiting Times for Suspected and Diagnosed Cancer Patients 2016-17 Annual Report. https://www.england.nhs.uk/statistics/statistical-work-areas/ Lest 25·4.2019.

4. Standardiserade vårdförlopp: Förkortade versioner för primärvården. 2017.12.o7 Version: 4.o. Stockholm: Regionala Cancercentrum, 2017.

https://www.cancercentrum.se/globalassets/vara-uppdrag/kunskapsstyrning/varje-dag-raknas/vardfor lopp/kortversioner/pdf/kortversion-svf-standardiserat-vardforlopp-sammanslagen.pdf Lest 25.4.2019.

5. Biganzoli L, Marotti L, Hart CD et al. Quality indicators in breast cancer care: An update from the EUSOMA working group. Eur J Cancer 2017; 86: 59-81. [PubMed][CrossRef]

6. Helsedirektoratet. Nasjonalt handlingsprogram med retningslinjer for diagnostikk, behandling og oppfølging av pasienter med brystkreft. IS-2736. Oslo: Helsedirektoratet, 2018.

https://www.helsedirektoratet.no/retningslinjer/brystkreft-handlingsprogram/Brystkrefthandlingspr ogram.pdf/_attachment/download/2b3fce62-

d2b2-4a11-95e1-443ad31c5dac:92co65f24d2b7e18c8b51653101fa451fdb2aed7/Brystkrefthandlingsprogram. pdf Lest 25.4.2019.

7. Helsedirektoratet. Pakkeforløp for kreft. https://helsedirektoratet.no/kreft/pakkeforlop-for-kreft Lest 26.10.2017.

8. Helsedirektoratet NP. Pakkeforløp for brystkreft.

https://www.helsedirektoratet.no/statistikk/statistikk/kvalitetsindikatorer/kreft-pakkeforlop/pakkefo rl\%C3\%B8p-for-brystkreft Lest 7.9.2018.

9. Helsedirektoratet. Pakkeforløp for 26 organspesifikke kreftformer.

https://www.helsedirektoratet.no/statistikk/statistikk/kvalitetsindikatorer/kreft-pakkeforlop/pakkefo rl\%C3\%B8p-for-brystkreft Lest 3.8.2018.

10. Pakkeforløp for brystkreft. IS-2517 Oslo: Helsedirektoratet, 2016.

11. Kvalitetsmanualen i Mammografiprogrammet. Oslo: Kreftregisteret, 2003.

https://www.kreftregisteret.no/globalassets/publikasjoner-og-rapporter/mammografiprogrammet/kv alitetsmanual_mammografiprogrammet.pdf Lest 25·4.2019.

12. Hofvind S, Tsuruda K, Mangerud G et al. The Norwegian Breast Cancer Screening Program, 1996-2016: celebrating 20 years of organised screening in Norway. Oslo: Kreftregisteret, 2017. https://www.kreftregisteret.no/globalassets/cancer-in-norway/2016/mammo_cin2016_special_issue_ web.pdf Lest 25.4.2019.

13. FOR-2001-12-21-1477. Forskrift om innsamling og behandling av helseopplysninger i Kreftregisteret (Kreftregisterforskriften).

14. Sagstad S, Sebuødegård S, Holen ÅS et al. Mammografiprogrammet - resultater fra prosessindikatorer 2006-2013/14. Oslo: Kreftregisteret, 2015.

https://www.kreftregisteret.no/globalassets/publikasjoner-og-rapporter/mammografiprogrammet/m ammografiprogrammet-resultater_fra_prosessindikatorer_2006-2014.pdf Lest 25.4.2019.

15. Larsen IK, Småstuen M, Johannesen TB et al. Data quality at the Cancer Registry of Norway: an overview of comparability, completeness, validity and timeliness. Eur J Cancer 2009; 45: 1218-31. [PubMed][CrossRef]

16. Brewer NT, Salz T, Lillie SE. Systematic review: the long-term effects of false-positive mammograms. Ann Intern Med 2007; 146: 502-10. [PubMed][CrossRef]

17. Brett J, Bankhead C, Henderson B et al. The psychological impact of mammographic screening. A systematic review. Psychooncology 2005; 14: 917-38. [PubMed][CrossRef] 
Publisert: 9. september 2019. Tidsskr Nor Legeforen. DOI: 10.4045/tidsskr.18.0322

Mottatt 12.4.2018, første revisjon innsendt 23.9.2018, godkjent 25.4.2019.

(C) Tidsskrift for Den norske legeforening 2020. Lastet ned fra tidsskriftet.no 